\title{
Bacillus subtilis sp. B1, Chitinase Producing Isolated from Indonesian Tropical Shrimp Pond Waste Water
}

\author{
Amrih Prasetyo ${ }^{1}$, Elisa Nurnawati ${ }^{2}$ \\ ${ }^{1}$ Balai Pengkajian Teknologi Pertanian Jawa Tengah, Tel. +62-298-5200107, Fax. +62-298-5200109, \\ J1. Soekarno - Hatta KM. 26 No 10, Bergas, Kabupaten Semarang 50552, Indonesia. \\ ${ }^{2}$ Departemen of Biology, Faculty of Mathematics and Natural Sciences, Sriwijaya University, Palembang, Indonesia \\ ${ }^{1}$ Email: amsetyo242@gmail.com
}

\begin{abstract}
Prasetyo A, Nurnawati E. 2017. Bacillus subtilis sp. B1, Chitinase Producing Isolated from Indonesian Tropical Shrimp Pond Waste Water. Proc Internat Conf Sci Engin 1: 1-4. Twenty-five bacterial strains isolated from shrimp farming ponds were screened for their growth activity on chitin as the sole carbon source. The highly chitinolytic bacterial strain was detected by qualitative cup plate assay and tentatively identified to be Bacillus subtilis sp. B1 based on 16S rDNA sequencing and by matching the key morphological, physiological, and biochemical characteristics. The cultivation of Bacillus subtilis sp. B1 in the suitable liquid medium resulted in the production of high levels of enzyme. The colloidal chitin, peptone, and $\mathrm{K}_{2} \mathrm{HPO}_{4}$ represented the best carbon, nitrogen, and phosphorus sources, respectively. Enzyme production by Bacillus subtilis sp. B1 was optimized by the Taguchi method. Our results demonstrated that inoculation amount and temperature of incubation were the most significant factors influencing chitinase production. From the tested values, the best $\mathrm{pH} /$ temperature was obtained at $\mathrm{pH} 4$ and $40{ }^{\circ} \mathrm{C}$, with values specific activity of chitinase to be $324.56 \mathrm{U} / \mathrm{mg}$ and 259.70 $\mathrm{U} / \mathrm{mg}$, respectively. In addition, the study of the morphological alteration of chitin treated by enzyme, indicating a potential application of this enzyme in several industries.
\end{abstract}

Keywords: Bacillus subtilis sp., Chitinase, Isolation, Shrimp Waste

\section{INTRODUCTION}

Chitinase roles in a variety of functions, including defense, nutrient digestion, morphogenesis, and pathogenesis. Most chitin-degrading prokaryotes are the gliding bacteria, pseudomonad, vibrio, enterobacteria, actinomycete, bacilli, and clostridia (Pinnamaneni, et al., 2011). Bacterial chitinases have a size range of 20-60 $\mathrm{kDa}$ (Lee, 2007). Chitinases have potential applications in various functions of biotechnology, biomedicine, agriculture, and nutrition (Narayana, 2009).

Bacillus organisms, isolated by tropical shrimp pond waste water, are responsible for producing chitinase. The most chitinase activity was seen in Bacillus subtilis. The most optimal activity occurs at a temperature of 37 degrees Celsius and a basic $\mathrm{pH}$ of $4-8$. Glycerol is the optimal carbon source and L-glutamic acid is the optimal source of nitrogen. The antibiotic bacitracin was determined to be affective on Gram-positive bacteria only (Jamil 2007). Other antibiotics that Bacillus subtilis form are polymyxin, difficidin, subtilin, and mycobacillin.

Bacillus subtilis bacteria secrete enzymes, such as amylase, protease, pullulanase, chitinase, xylanase, lipase, among others. These enzymes are produced commercially and this enzyme production represents about $60 \%$ of the commercially produced industrial enzymes (Morikawa 2006).

This study aimed to gain superior isolates chitinolytic bacteria capable of degrading chitin from shrimp waste, especially in the tropical shrimp pond. Characterize isolates with the highest chitinase activity based on morphology, biochemistry and molecular identified isolates.

\section{MATERIALS AND METHODS}

\section{Isolation of bacteria}

Samples collected from Indonesian tropical shrimp pond waste water located in Srandakan, Bantul-Yogyakarta and used for isolation studies in our laboratory.

\section{Screening of chitinase-producing bacteria}

The isolated bacterias were cultured on agar plates containing $0.5 \%$ colloidal chitin, $0.07 \% \mathrm{~K}_{2} \mathrm{HPO}_{4}, 0.03 \%$ $\mathrm{KH}_{2} \mathrm{PO}_{4}, 0.05 \% \mathrm{MgSO}_{4} \cdot 7 \mathrm{H}_{2} \mathrm{O}, 2 \%$ agar, $0.2 \% \mathrm{NH}_{4} \mathrm{NO}_{3}$, $0.1 \% \mathrm{NaCl}(\mathrm{w} / \mathrm{v})$, and $(\mathrm{pH} 7.8)$. The cultures were incubated for 5 days at 30 degrees Celsius. Only one chitinolytic bacterial strain (detected by a colony producing a halo around itself) was transferred into fresh chitin containing nutrient broth medium and incubated at 30 degrees Celsius, following which, the strain was preserved as cell suspensions in $10 \%$ glycerol at -80 degrees Celsius (Hau, 1975).

\section{Enzyme Assay}

The assay was carried out as described by Imoto and Yagishita (1971). Briefly, a reaction mixture containing $1.0 \mathrm{ml}$ of $0.5 \%$ colloidal chitin, $2.0 \mathrm{ml}$ of $0.2 \mathrm{M}$ $\mathrm{Na}_{2} \mathrm{HPO}_{4}-\mathrm{O} .1 \mathrm{M}$ citric acid buffer ( $\mathrm{pH} 5.4$ ), and $1.0 \mathrm{ml}$ of enzyme solution. After incubation with shaking for 20 min at 37 degrees Celsius, the mixture was heated for 15 min at 100 degrees Celsius and optical density was determined at $420 \mathrm{~nm}$. Reducing sugars produced in the 
supernatant were measured by a modification of Schales method, with Nacetyl glucosamine as a standard. One unit of enzyme activity was defined as the amount of enzyme that required releasing $1 \mu \mathrm{mol}$ of Nacetyl glucosamine per hour (U/mg).

\section{Strain Identification}

The isolates were analyzed for species identity using the 16S rRNA gene sequencing method according to Rochelle et al., (1995). The gene sequencing was performed at Biotech Laboratory (UGM Univ). DNA sequences were aligned using DNA star and Data Collection v3.1 Communication Patch 1. Bacterial 16S rRNAs were amplified by using the following universal bacterial 16S rRNA primers. Forward primer $27 \mathrm{~F}$ (5'AGAGTTTGATCMTGGCTCAG-3') and reverse primer $1792 \mathrm{R}$ (5'-TACGGYTACCTTGTTACGACTT3') (Gomaa, 2012).

Sequencing products were sequenced on an Applied Biosystems model ABI PRISM 3100 Hitachi, automated DNA sequencing system (Japan). All the sequence of strain were analyzed by using Basic Local Alignment Search Tool for Nucleotides (BLASTN, NCBI, USA).

\section{RESULTS AND DISCUSSION}

Forty water samples were collected from shrimp pond waste water located in Srandakan, Bantul, Yogyakarta, from these samples different bacterial colonies were isolated and identified as Bacillus. The identification of the bacteria morphological features like shape, colour and size of the colonies were compared with reference isolate B1 as Bacillus subtilis

Domain: Bacteria, phylum: Firmicutes, class: Bacilli, order: Bacillales, family: Bacillaceae, Genus: Bacillus subtilis (Claus and Berkeley, 1986).

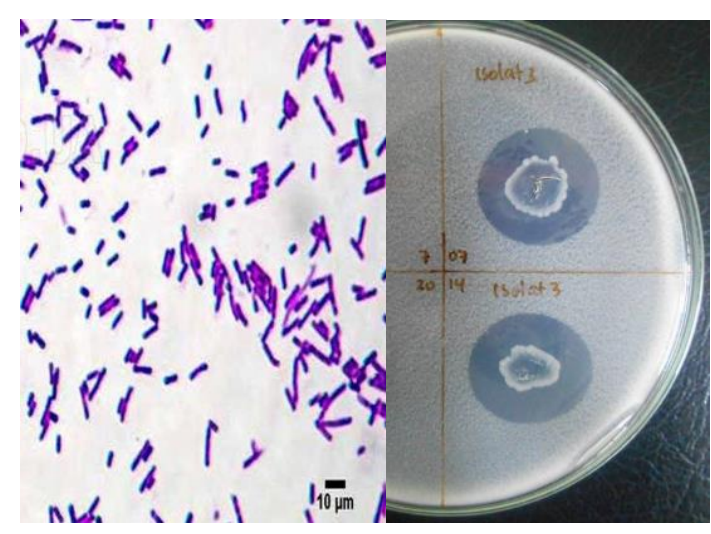

Figure 1. Gram stain and clear zone of Bacillus subtilis sp. B1.

The clearing zones were measured after the five days incubation. Among those strains, five strains, which gave the biggest chitinolytic ratio of clearing zones, were selected. Gram staining of bacteria showed Bacillus and Gram positive (Fig. 1). This figure showed the chitinase production by colloidal chitin medium by the isolated B.subtilis. B1 strains were used to screen for cleared zone around colony.

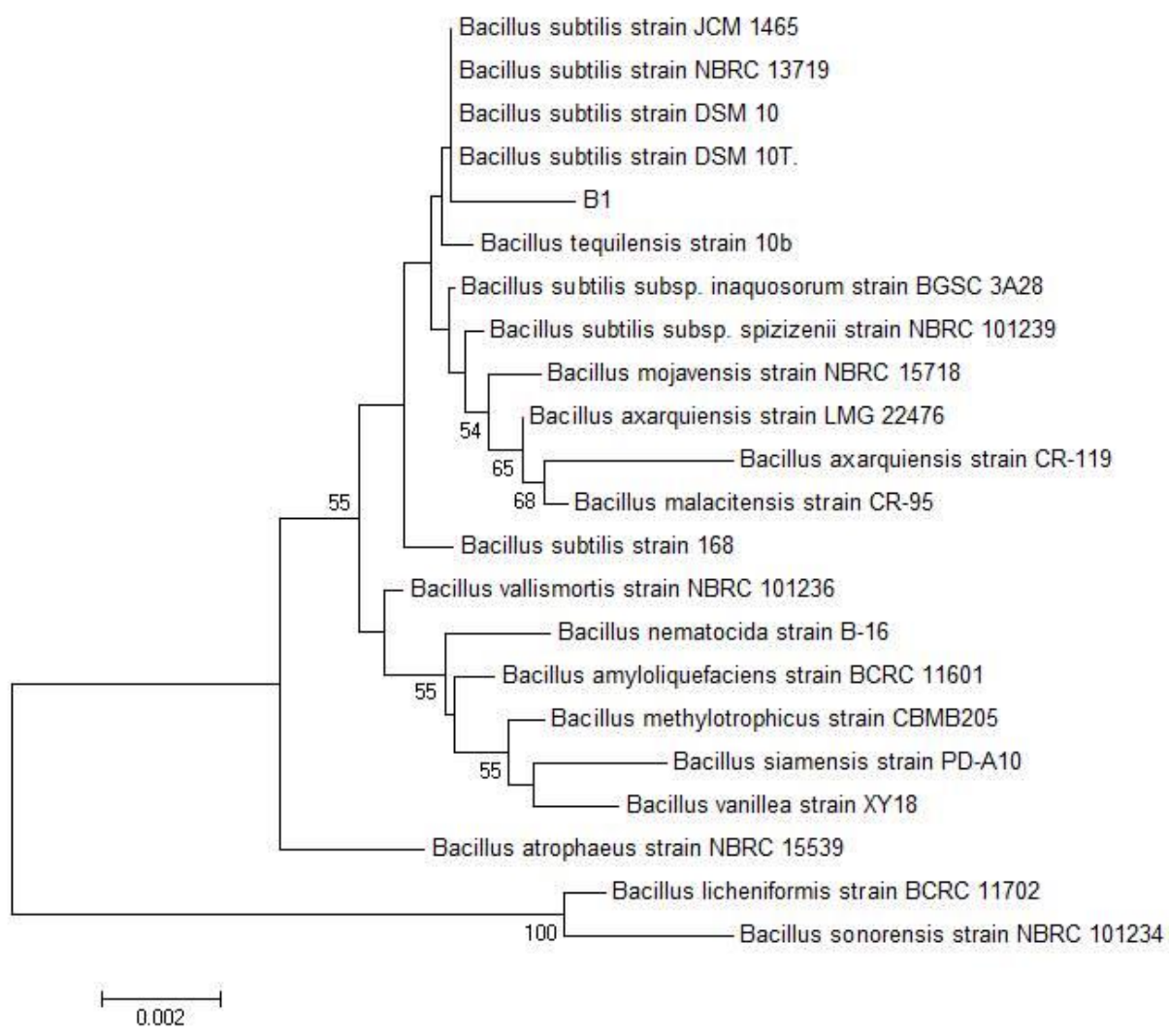

Figure 2. Neighbour-joining phylogenetic tree based on $16 \mathrm{~S}$ rRNA gene sequences showing the positions of strain B-1 Bacillus subtilis sp. The scale bar corresponds to 0.002 subscriptions per nucleotide position. 
The sequences were aligned using clustalW and a phylogenetic tree was constructed using MEGA 6. Rooted Neighbour-Joining (NJ) tree showing phylogenetic relationship among different B. subtilis isolates based on nucleotide region of ribosomal $16 \mathrm{~S}$ rRNA sequences genes (Fig. 2).

In our research the $16 \mathrm{~S}$ rRNA gene sequence analyses provided very good identification of the isolates at the genus level. Other studies also been reported that analysis of $16 \mathrm{~S}$ rRNA gene sequences alone was not sufficient to identify Bacillus species (Lima et al., 2007).

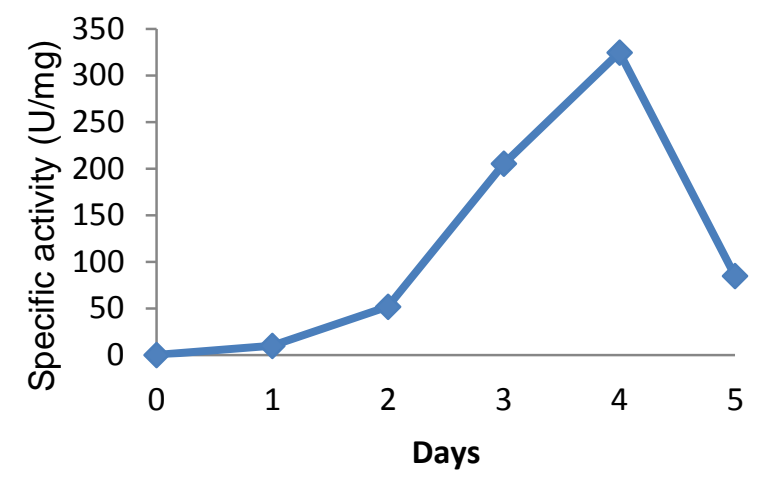

Figure 3. The optimum $\mathrm{pH}$ for the production of chitinase enzyme was found at $\mathrm{pH} 4$.

The $\mathrm{pH}$ of the immediate external environment partially governs the cytoplasmic $\mathrm{pH}$ and is believed to affect the rate of enzyme mediated reaction and structure of many biological molecules including proteins and nucleic acids. The present study reports appreciable chitinase production between $\mathrm{pH} 4.0$ and 8.0, with the maximum $(324.56 \mathrm{U} / \mathrm{mg}$ ) recorded at $\mathrm{pH} 4.0$, enzyme yield was observed under acidic conditions (Fig. 3).

This is similar to the $\mathrm{pH} 5$ reported for Bacillus circulans WL-12 (Watanabe et al., 1992). So similar to pH 6 for Vibrio sp. strain 98CJ11027 (Park et al., 2000), pH 5 and 7 for Bacillus sp. strain JK2 (Jami Al Ahmadi et al., 2008) and pH 5-8 for Aeromonas hydrophila $\mathrm{H}$ 2330 (Hiraga et al., 1997).

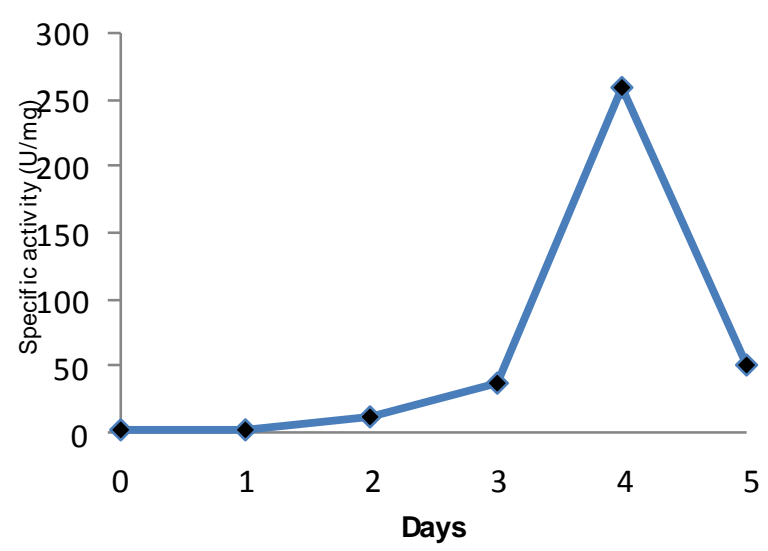

Figure 4. The optimum temperature for the production of chitinase enzyme was found at 40 degrees Celsius and $\mathrm{pH} 7$.
When B. subtilis was grown at 30-50 degrees Celsius, chitinase production was maximum (259.70 $\mathrm{U} / \mathrm{mg}$ ) at 40 degrees Celsius. The enzyme production decreased above 50 degrees Celsius (Fig. 4). This result indicated the organism's mesophilic preference for enzyme production.

The temperature effect of the chitinase activity was also performed which indicated that the activity was increased to the temperature below the optimum temperature at 40 degrees Celsius and decrease at a higher temperature.

Biochemical and microbiological analyses were performed to characterize the screened strain (Table 1). In accordance with the Bergey's Manual of Systematic Bacteriology, the B1 strain was classified as a bacteria belonging to the genus $B$. subtilis.

Chitinase production was induced by chitin and inhibited in the presence of easily metabolized monosaccharides, such as glucose, galactose, mannose, arabinose, and fructose.

Table 1. Morphological, physiological and biochemical characteristic of B. subtilis $\mathrm{sp}$. B1.

\begin{tabular}{ll}
\hline Characters & Results \\
\hline \hline Form & Rod \\
Gram stain & Positive \\
Spore & Spore central \\
Motility & Positive \\
Catalase & Positive \\
Oxidase & Negative \\
Utilization of & \\
$\quad$ Glucose, maltose & Positive \\
Arabinose, xylose, mannitol, lactose, & Negative \\
Hydrolysis of starch & Positive \\
Growth on NaCl & Positive \\
Growth temperature & $30-50$ degrees Celsius \\
\hline
\end{tabular}

\section{CONCLUSIONS}

This study shows that the $B$. subtilis isolates are highest similarity between the NCBI deposited isolates i.e. $97-$ 99\%. 16S rRNA nucleotide sequence will be informative and useful in detecting the genetic diversity of populations of $B$. subtilis. This strain may be useful for the treatment of chitinous waste and also for production many products of hydrolyzed chitin.

\section{ACKNOWLEDGeMENTS}

This work was supported by Indonesian Agency for Agricultural Research and Development Ministry of Agriculture, Faculty of Animal Science Universitas Gadjah Mada and Faculty Applied Biology of Science, Gifu University Japan. 


\section{REFERENCES}

Claus, D. and Berkeley, R. C. W. 1986. Genus Bacillus Chon 1872. In: Sneath P H A, Mair N S, Sharpe M E, Holt J G, editors. Bergey's Manual of Systematic Bacteriology. Vol. 2. Baltimore, Md: The Williams \& Wilkins Co. pp. 613-634

Gomaa, E. Z. 2012. Chitinase production by (Bacillus thuringiensis) and (Bacillus licheniformis): their potential in antifungal biocontrol. J. Microbiol. 50: 103 - 11 .

Hau SC, Lockwood JL. 1975. Powdered chitin agar as a selectivemedium for enumeration of actinomycetes in water and soil. Appl Microbiol. 29: 422-426

Hiraga, K., Shou, L., Kitazawa, M., Takahashi, S., Shimada, M., Sato, R. and Oda, K. 1997. Isolation and characterization of chitinase from a flake-chitin degrading marine bacterium, Aeromonas hydrophila H-2330. Bioscience Biotechnology and Biochemistry. 61: 174-6.

Imoto, T., and Yagishita, K. 1971. A simple activity measurement of lysozyme. Agricultural and Biological Chemistry, 35 (7), $1154-1156$.

Jami Al Ahmadi, K., Yazdi, M. T., FathiNajaf, M., Shahverdi, A., Fararnarzi, M., Zarrini, G., and Behravan, I. 2008. Isolation and characterization of a chitinolytic enzyme-producing microorganism, Paenibacillus chitinolyticus IK2 from Iran. Res. J. Microbiol. 3: 395-404.

Jamil, B, 2007. "Isolation of Bacillus subtilis MH-4 from Soil and its Potential of Polypeptidic Antibiotic Production". Pak J Pharm Sci. January; 20 (1) :26-31

Lee YS, Park IH, Yoo JS. 2007. Cloning, purification, andcharacterization of chitinase from Bacillus sp. DAU101. Bioresour Technol. 98: 2734-2741.
Lima - Bittencourt, C. I., Astolfi - Filho, S., Chartone - Souza, E., Santos, F. R., Nascimento, A. M., 2007. Analysis of Chromobacterium sp. natural isolates from different Brazilian ecosystems. BMC Microbiol, 7: 1-9

Morikawa, M., 2006. "Beneficial Biofilm Formation by Industrial Bacteria Bacillus subtilis and Related Species". Journal of Bioscience and Bioengineering. Vol.101, No.1, 1-8.

Narayana KJ, Vijayalakshmi M. 2009. Chitinase production byStreptomyces sp. ANU 6277. Braz J Microbio 140:725-733

Park, S. H., Lee, J. H. and Lee, H. K. 2000. Purification and characterization of chitinase from a marine bacterium, Vibrio sp. 98CJ11027. Journal of Microbiology. Seoul. $38: 224-229$.

Pinnamaneni R, Kalidas P, Sambasiva Rao KR. 2011. Studies on the cloning and expression of Bbchit1 gene of Beauveria bassiana NCIM 1216. Indian J Microbiol.51:396-402

Rochelle, P., Will, J., Fry, J., Jenkins, G., Parkes, R., Turley, C., and Weightman, A. 1995. Extraction and amplification of $16 \mathrm{~S}$ rRNA genes from deep marine sediments and seawater to assess bacterial community diversity, in Nucleic Acids in The Environment. Springer. pp. $219-239$.

Wang SY, Zhou JJ, Shao B, Lu YJ, Rao PF. 2008. A thermostablechitinase with chitin-binding activity from Phaseolus limensis. J Food Sci. 73: C452-C457

Watanabe, T., Oyanagi, W., Suzuki, K., Ohnishi, K. And Tanaka, H. 1992. Structure of the gene encoding chitinase D of Bacillus circulans WL-12 and possible homology of the enzyme to other prokaryotic chitinases and class III plant chitinases. The Journal of Bacteriology. 174: 408-414. 